Effects of Non-latching Blast Valves on the Source Term and Consequences of the Design-Basis Accidents in the Device Assembly Facility (DAF)

\author{
Dong H. Nguyen
}

Marluscript date: August 1993 


\section{Contents}

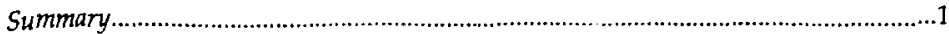

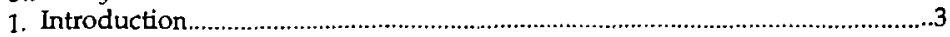

2. Characteristics of the DAF Non-Latching Valves.........................................4

2.1 Location.............................................................................................4

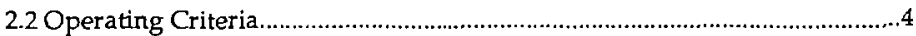

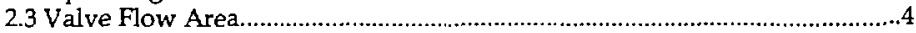

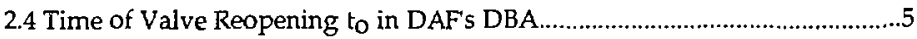

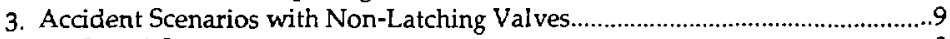

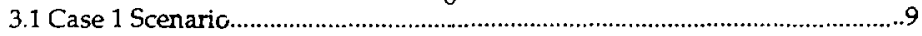

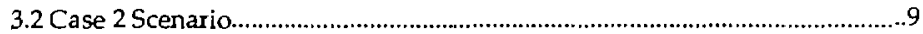

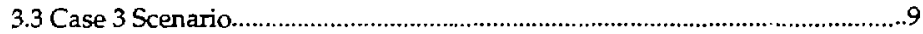

$\therefore$ Consequences of DBA Case 1 with Non-Latching Blast Valves.......................11

4.1 Intrafacility Pu Transport......................................................................11

4.2 Relesase to the Environment (Source Term) ................................................11

4.3 Occupational Consequences to DAF Personnel..........................................18

5. Consequences of DBA Case 2 with Non-Latching Valves..............................23

6. Consequences of DBA Case 3 with Non-Latching Valves..............................31

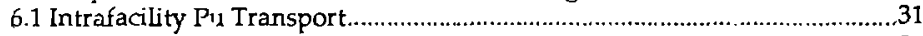

6.2 The Source Term...................................................................................., 31

6.3 Occupational Consequences to DAF Personnel......................................31

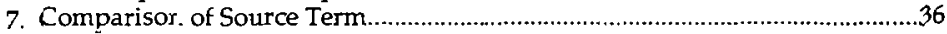

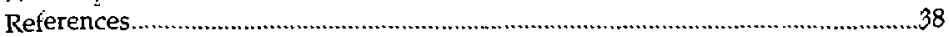

\section{List of Figures}

1. Assembly Cell air flow..........................................................................

2. Flow resistance for a PV-6-350 blast valvi ....................................................8

3. Suspended $\mathrm{Pu}$ in staging area. Comparison of various accident cases with latching and non-latching valves.........................................................12

4. Suspended Pu in personnel vestibules. Comparison of behavior with latching and non-latching valves. Case 1: $423 \# \mathrm{HE}, 16 \mathrm{~kg}$ Pu.................13

5. Suspended $\mathrm{Pu}$ in equipment vestibules. Comparison of behavior with latching and non-latching valves. Case 1: 423\# $\mathrm{HE}, 16 \mathrm{~kg} \mathrm{Pu}$.................14

6. Suspended Pu in corridor. Comparison of behavior with latching and non-latching valves. Case 1: 423 \#E, $16 \mathrm{~kg} P \mathrm{Pu}$

7. Suspended $\mathrm{Pu}$ in Decon room and radiography building. Comparison of behavior with latching and non-latching valves.

Case 1: 423\# HE, $16 \mathrm{~kg} \mathrm{Pu}$

8. Components of unfiltered source term: Roof lift, non-latching valve and gravel (latching and non-latching)-Case 1: 423\# HE, $16 \mathrm{~kg}$ Pu......................17

9. Total source term (Pu release to the environment): Comparison between filtered and unfiltered release, with latching and non-latching valves.

Case 1: 423 HE, $16 \mathrm{~kg} \mathrm{Pu}$ 
10. Suspended $\mathrm{Pu}$ in corridor. Comparisnn of behavior with latching and non-latching valves. Case 2: 150\# HE, $10 \mathrm{~kg} P$ Pu.................24

11. Suspended $\mathrm{Pu}$ in Decon room and radiography $\mathrm{k}$ jilding. Comparison of inehavior with latching and non-latching valves.

Cáse 2: 150\# HE, $10 \mathrm{~kg} \mathrm{Pu}$

12. Con:ponents of unfiltered source tern: Roof lift, non-latching valve and gravel (latching and non-latching)-Case 2: $15(0 \# \mathrm{HE}$ : $10 \mathrm{~kg} \mathrm{Pu}$

13. Tolal source term (Pu release to the environment): Comparison between filtered and unfiltered release, with latching and non-latching valves.

Case 2: 150\# HE, $10 \mathrm{~kg}$ Pu.

14. Comparison of total $\mathrm{Pu}$ in respirable size range, in the gravel gertie for Case 3, with latching and non-latching valves.

15. Suspended Pu in corridor. Comparison of behavior with latching and non-latching valves. Case 3: 50\# $\mathrm{HE}, 5 \mathrm{~kg} \mathrm{Pu}$

16. Suspended $\mathrm{Pu}$ in Decon room and radiography building. Comparison of behavior with latching and non-latching valves. Case 3: 50 \# HE, $5 \mathrm{~kg}$ Pu.....33

17. Total source term (i u release to the environment): Comparison between filtered and unfiltered release, with latching and non-latching valves.

Case 3: 50\# HE, $5 \mathrm{~kg} \mathrm{Pu}$.

\section{List of Tables}

1. Times of valve reopening $t_{0}$. 6

2. Source term from DAF Design-Basis Accideni - Case 1: 423 \#E, $16 \mathrm{~kg}$ Pu...20

3. 50-year conumitted doses in upstream corridor (respiration at $20 \mathrm{l} / \mathrm{min}$ ) Comparison between consequences with latching (in parentheses) and non-latching valves for Case 1: $423 \# \mathrm{HE}$, 1 ć kg Pu.

4. 50-year committed doses in downstream corridor (respiration at $201 / \mathrm{min}$ ) Comparison between consequences with latching (in parentheses) and non-latching valves for Case $1: 423 \# \mathrm{HE}, 16 \mathrm{~kg} \mathrm{Pu}$

5. 50-year committed doses in decon room (respiration at $20 \mathrm{l} / \mathrm{min}$ ) Comparison between consequences with latching (in parentheses) and non-latching valves for Case $1: 423 \# \mathrm{HE}, 16 \mathrm{~kg}$ Pu 22

6. 50-year committed doses in radiography building (respiration at $201 / \mathrm{min}$ ) Comparison between consequences with latching (in parentheses) and non-latching valves for Case 1: $423 \# \mathrm{HE}, 16 \mathrm{~kg}$ Pu.

7. Source term from DAF Design-Basis Accident -Case 2: $150 \# \mathrm{HE}, 10 \mathrm{~kg}$ Pu....28

8. 50-year committed doses in upstream corridor (respiration at $20 \mathrm{l} / \mathrm{min}$ ) Comparison between consequences with latching (in parentheses) and non-latching valves for Case 2: $150 \# \mathrm{HE}, 10 \mathrm{~kg}$ Pu

9. 50-year committed doses in downstream corridor (respiration at $201 / \mathrm{min}$ )

Comparison between consequences with latching (in parentheses) and non-latching valves for Case 2: 150\# HE, $10 \mathrm{~kg}$ P11. 
10. 50-year committed doses in decon room (respiration at $201 / \mathrm{min}$ ) Comparison between consequences with latching (in parentheses) and non-latching valves for Case 2: 150 \# $\mathrm{HE}, 10 \mathrm{~kg}$ Pu.

11. 50-year committed doses in radiography building (respiration at $201 / \mathrm{min}$ ) Comparison between consequences with latching (in parentheses) and non-latching valves for Case 2: $150 \# \mathrm{HE}, 10 \mathrm{~kg} \mathrm{Pu}$.

12. Source term from DAF Design-Basis Accident -Case 2: $150 \#$ HE, $10 \mathrm{~kg}$ Pu....35

13. Comparison of unfiltered source term components ( $\mathrm{gm} \mathrm{Pu}$ ) for the three $\mathrm{DBA}$, with latching ( $\mathrm{L}$ ) and non-latching (NL) valves .36

14. Comparison of filtered source term components ( $\mathrm{gm} \mathrm{Pu}$ ) for the three $\mathrm{DBA}$, with latching (L) and non-latching (NL) valves .36

15. Comparison of total unfiltered and filtered source terms ( $\mathrm{gm} \mathrm{Pu}$ ) for the three DBA, with latching (L) and non-latching (NL) valves 


\title{
Effects of Non-Latching Blast Valves on the Source Term and Consequences of the Design-Basis Accidents in the Device Assembly Facility (DAF)
}

\begin{abstract}
Summary
The analysis of the Design-Basis Accidents (DBA) involving high explosives (HE) and Plutonium (Pu) in the assembly cell of the Device Assembly Facility (DAF), which was completed earlier (Ref. 2), assumed latching blast valves in the ventilation system of the assembly cell. Latching valves effectively sealed a release path through the ventilation duct system. However, the blast valves in the assembly cell, as constructed are actually non-latching valves, and would reopen when the gas pressure drops to $0.5 \mathrm{psi}$ above one atmosphere. Because the reopening of the blast valves provides an additional release path to the environment, and affects the material transport from the assembly cell to other DAF buildings, the DOE/NV DAF management has decided to support an additional analysis of the DAF's DBA to account for the effects of non-latching valves (Ref. 3).
\end{abstract}

Three cases were considered in the DAF's DBA, depending on the amount of HE and $\mathrm{Pu}$ involved, as follows:

DAF Design-Basis Accidents

\begin{tabular}{lrr}
\hline Case number & $\mathrm{HE}, \#$ & $\mathrm{Pu}, \mathrm{kg}$ \\
\hline & & \\
Case 1 & 423 & 16 \\
Case 2 & 150 & 10 \\
Case 3 & 55 & 5 \\
\hline
\end{tabular}

The results of the analysis with non-latching valves are summarized as follows:

- When the amount of $\mathrm{HE}$ was sufficient to cause the collapse of the gravel gertie (GG) roof, such as in Cases I \& 2 of the DBA, the non-latching valves would reopen at an earlier time than for the case without GG collapse (DBA Case 3). The time of valve reopening was $0.9 \mathrm{sec}$ and $0.8 \mathrm{sec}$ for Case 1 and Case 2, respectively, compared to $1430 \mathrm{sec}$ for Case 3.

- For Cases $1 \& 2$, the early reopening of the valves caused an increase in the early Pu release to the environment (during the first few minutes). At the same tirre, the build-up of respirable Pu in other DAF buildings (equipment and personnel vestibules, corridor, decontamination room, radiography building and high bays) was reduced. A significant reduction in occupational doses to DAF personnel ensued in these locations for Cases $1 \& 2$, even during the early phase 
of the accident (first few minutes). For case 3 of the DBA, there was no change in the occupational consequences to DAF personnel during the first 24 minutes or so, prior to the reopening of the valves.

- For Cases $1 \& 2$, although the Pu release to the environment (source term) with non-latching valves was higher than that with latching valves for the first several minutes, the long-term release was only slightly higher for nonlatching valves. The reason was that in Cases $1 \& 2$, there were several vening paths beside the reopened valve. The reopened valve did accelerate the venting of the staging area, resulting in an increase in Pu release during the first few minutes following the valve reopening. This increased venting caused a faster depressurization of the staging area, with subsequent reduction in the flow of $\mathrm{Pu}$ to the environment. The results for Case 3 were different. For this case, the GG did not collapse. The valve, which reopened at a much later time, was the only large venting path. The reopened valve quickly depleted the Pu concentration in the source location, the gravel gertie. This was followed by a quicker decrease of $\mathrm{Pu}$ concentration in other DAF buildings after the valve reopened. For Case 3 , although the shorter term (first 24 minutes, before valve reopening) Pu traisport and occupational consequences of DAF personnel were not affected, the longterm Pu release to the environment was significantly higher than the case with latching valves. The long-term Pu concentrations in the DAF buildings outside the GG and staging area were also reduced, but the largest reduction was in the GG itself. 


\section{Effects of Non-Latching Blast Valves on the Source Term and Consequences of the Design-Basis Accidents in the Device Assembly Facility (DAF)}

\section{Introduction}

According to DOE Order 5480.23,"Design-Basis Accidents (DBA) are postulated for the purpose of establishing functional requirements for safety significant structures, systems, components and equipments." (Ref. 1). For the Device Assembly Facility (DAF), three cases of DBA have been defined to cover the range of likely operating conditions in the Gravel Gertie (GG). These cases were defined, depending on the quantity of high explosive (HE) and Plutorium (Pil) inyolved, as follows.

- Case 1: 423 \# HE, $16 \mathrm{~kg} \mathrm{Pu}$.

- Case 2: 150 \# HE, $10 \mathrm{~kg}$ Pu.

- Case 3: 55 \# HE, $5 \mathrm{~kg}$ Pu.

Cases 1 and 2 involved sufficient HE to cause the lifting and collapse of the GG. Case 3 did not cause the collapse of the gravel roof, and led to a very different accident scenario. The containment analysis of these cases of BDA has been completed earlier (Ref. 2). The analysis determined the transport of respirable $\mathrm{Pu}$ aerosols throughout the $\mathrm{DAF}$, and the ensuing occupational doses received by the DAF personnel at various locations, as well as the total Pu release to the environment (Source Term). At the time of the analysis reported in Reference 2, the blast valves of the ventilation system in the assembly cell were intended to be latching valves. The analysis in Reference 2 then assumed that these valves, once closed by the blast, would remain closed, thus effectively shutting off the ventilation duct system in the assembly cell throughout the accident. It has recently become clear that the existing blast valves in the assemibly cell, which are nor-latching, will not be modified to become latching valves. These valves, by design, would reopen when the blast dies away, at the static pressure of $0.5 \mathrm{psi}$ above one atmosphere. The recpened valves would provide an additional path for Pu release to the environment, thereby affecting the source term and the transport of Pu aerosols thrcughout the DAF buildings. Although intuitive engireering considerations would predict an increase in the source term, and a decrease in the Pu contamination of various DAF buildings along the corridor, the DOE DAF Project manager decided to support a study to determine the quantitative effects of the non-latching valves on the consequences of the DBA postulated earlier. This report describes the results of this study. 


\section{Characteristics of the DAF Non-Latching Valves}

The location of the valves in the assembly cell, their flow area, and the time of their reopening under DAF's DBA conditions are required for this analysis.

\subsection{Location}

The air flow diagram in the assembly cell is shown in Figure 1. The blast valves used in this ventilation system were supplied by Temet USA., Inc. A 10" valve (PV-6-250) is installed in the task exhaust that is activated only in "hoodon" operations. A 14" valve (PV-6-350) is installed in the relief exhaust, which under normal operations (hood-off), releases air at a rate of $500 \mathrm{~cm}$. Another 14" valve is located in the inlet duct, which, also under normal operations, supplies air to the assembly cell at a rate of $330 \mathrm{~cm}$ through a recirculation circuit. At the same time, air infiltrates to the assembly cell from the personnel and equipment vestibules at the rates of $70 \mathrm{~cm}$ and $100 \mathrm{cfm}$, respectively. In this analysis, it was assumed that if the GG was destroyed following the accident, the task exhaust path would be blocked. If the blast did not cause the GG to collapse, it was assumed that the system was under normal operations (hood-off) conditions. The valve connected to the recirculation system was assumed to have a minimal effect on the environmental release. With these assumptions, only the 14 " valve in the relief exhaust played a major role in the accident scenario.

\subsection{Operating Criterid}

Information provided by Temet USA, Inc. includes the following operating characteristics of the PV-6-350 valve:

- Valve would be in closed position $20 \mathrm{msec}$ after onset of blast front.

- Valve would reopen when gas pressure drops to po, where

$$
\text { po }=\text { one atmosphere }+0.5 \mathrm{psi}
$$

Discussions with Temet representatives indicated that the valve should/reopen fully within $1 \mathrm{sec}$ after the ambient pressure drops to po.

\subsection{Valve Flow Area}

The flow area was determined from the flow rosistance curve provided by Temet USA (Figure 2), as follows. From Curve $A$ of the figure (flow direction from the blast side to the protected side), the flow resistance is $1.55 \mathrm{~m}^{3} / \mathrm{sec}$ at a pressure differential of 200 pascals ( $1 \mathrm{psi}=6.8947610^{3}$ pascals). Assuming isentropic flow through the valve, the flow rate is related to the pressure and flow area as follows: 


$$
w=A\left\{\frac{2 k g_{c}}{k-1} \frac{p_{2}}{\rho_{1}}\left[1-\left(\frac{p}{p_{1}}\right)^{\frac{k-1}{k}}\right]\right\}^{1 / 2}=A V
$$

where

$$
\begin{array}{lll}
w & = & \text { flow rate }(\mathrm{ft} / \mathrm{sec}) \\
\mathrm{A} & =\text { flow area }\left(\mathrm{ft}^{2}\right) \\
\mathrm{V} & =\text { flow velocity }(\mathrm{ft} / \mathrm{sec}) \\
\mathrm{p} 1 & =\text { upstream pressure }\left(\mathrm{lb} / \mathrm{ft}^{2}\right) \\
\mathrm{p} & =\text { downstream pressure }\left(\mathrm{lb} / \mathrm{ft}^{2}\right) \\
\rho 1 & =\text { upstream fluid density }\left(\mathrm{lbm} / \mathrm{ft}^{3}\right) \\
\mathrm{k} & =\text { ratio of specific heats for air }(1.4)
\end{array}
$$
calculated:

Assuming $\mathrm{p} 1=1$ atmosphere ( $12.77 \mathrm{psi}$ at NTS), the valve flow area was

$$
A \quad=\quad 0.912 \mathrm{ft}^{2} \text { or } 0.0847 \mathrm{~m}^{2} \text {. }
$$

It is noted that according to the operation and maintenance manual of these valves, they may fail to reopen automatically if subjected to blast pressures beyond its design imits. Then, the accident scenarios are reduced to the cases with latching valves analyzed in Reference 2 .

\subsection{Time of Valve Reopening $t_{o}$ in DAFs DBA.}

A reopened valve introduces an additional fluw path for the release of $\mathrm{Pu}$ to the environment. The time at which this additionai flow path becomes effective is an important parameter in the analysis of accident consequences. We determined the tirne of valve reopening according to the criterion of Equation 1.

- Case I (423 \# HE, $16 \mathrm{~kg} \mathrm{Pu}$ ). The 1982 full-scale test involved the amount of $\mathrm{HE}$ corresponding to this case. The gas pressure in the staging area measured by the SouthWest Research Institute (SWRI) in this test (see Figure 13 of Ref. 2) was used to find the time at which the gas pressure decreased to $p_{0}$ (time of valve reopening $t_{0}$ ). This time was found to be $t_{0}=0.9 \mathrm{sec}$. Use of the calculated pressure (Ref. 2) also led to the same result.

- Case $2(150 \# \mathrm{HE}, 10 \mathrm{~kg} \mathrm{Pu})$. We used the calculated pressure history (Ref. 2) to determine $t_{0}$, and obtained $t_{0}=0.8 \mathrm{ser}$.

- Case 3 (55 \# HE, $5 \mathrm{~kg}$ Puj. IVe also used the calculated pressure to determine the time of valva reopening $t_{c}$. Because the GG did not collapse, the 
depressurization of the assembly cell through the leak path of the blast doors was a slow process, and the pressure in the staging area did not reach $p_{0}$ until relatively late in the accident sequence. For this case, an interpolation of the calcul ated pressure was needed to determine the time of po. This was accomplished by assuming an exponential depressurization in a vented compartment:

$$
p(t)=p_{\max } e^{-\alpha t},
$$

so that, between any two times $\mathrm{t} 1$ and $\mathrm{t} 2$

$$
\frac{p_{1}}{p_{2}}=\exp -a\left(t_{1}-t_{2}\right)
$$

The decay constant "a" can be determined from the calculated p1 and p2. From the results of the pressure calculations, it can be determined that po was attained between $t_{1}=1240 \mathrm{sec}$ and $t_{2}=1640 \mathrm{sec}$. Using $\mathrm{P}_{1}$ and $\mathrm{P}_{2}$ at these times allowed the determination of a:

$$
a=4.3393 \text { sec- }-1 \text {, }
$$

and the time of valve reopening $t_{0}$ :

$$
t_{0}=1430 \mathrm{sec}
$$

The times of valve reopening for the three cases of DAFs DBA are summarized in Table 1.

Table 1

Times of valve reopening to

DBA Case to, sec

Case 1 (423 \# HE, $16 \mathrm{~kg} \mathrm{Pu}$ )

0.9

Case 2 , 150 \# HE, $10 \mathrm{~kg} \mathrm{Pu}$ )

Case 3 (55 \# HE, $5 \mathrm{~kg} \mathrm{Pu}$ ) 
Fiqure 1. Assemb!y Air flow

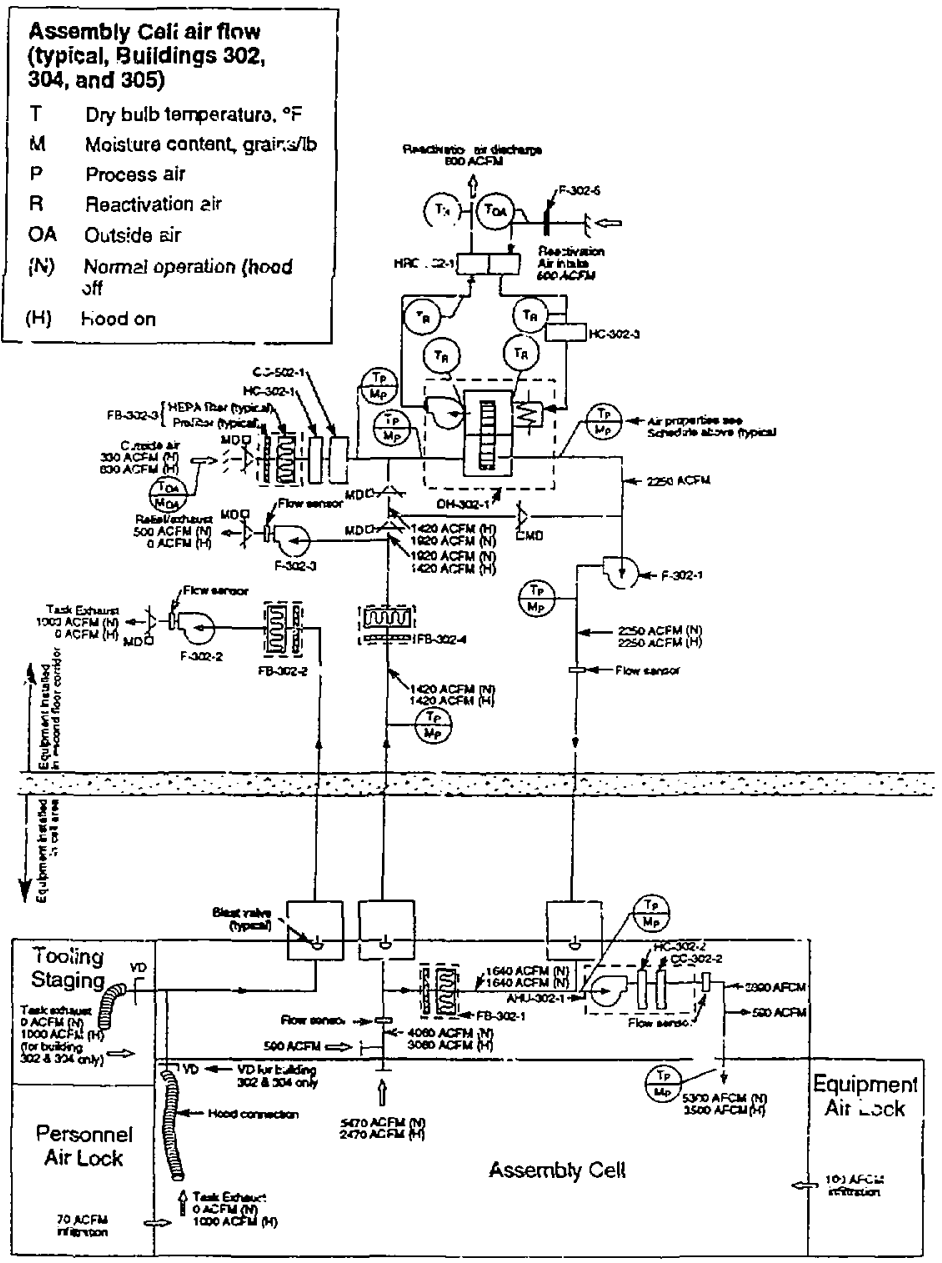




$$
\text { Mar-2E-93 FRI } 13=30 \text { TEMET USA }
$$

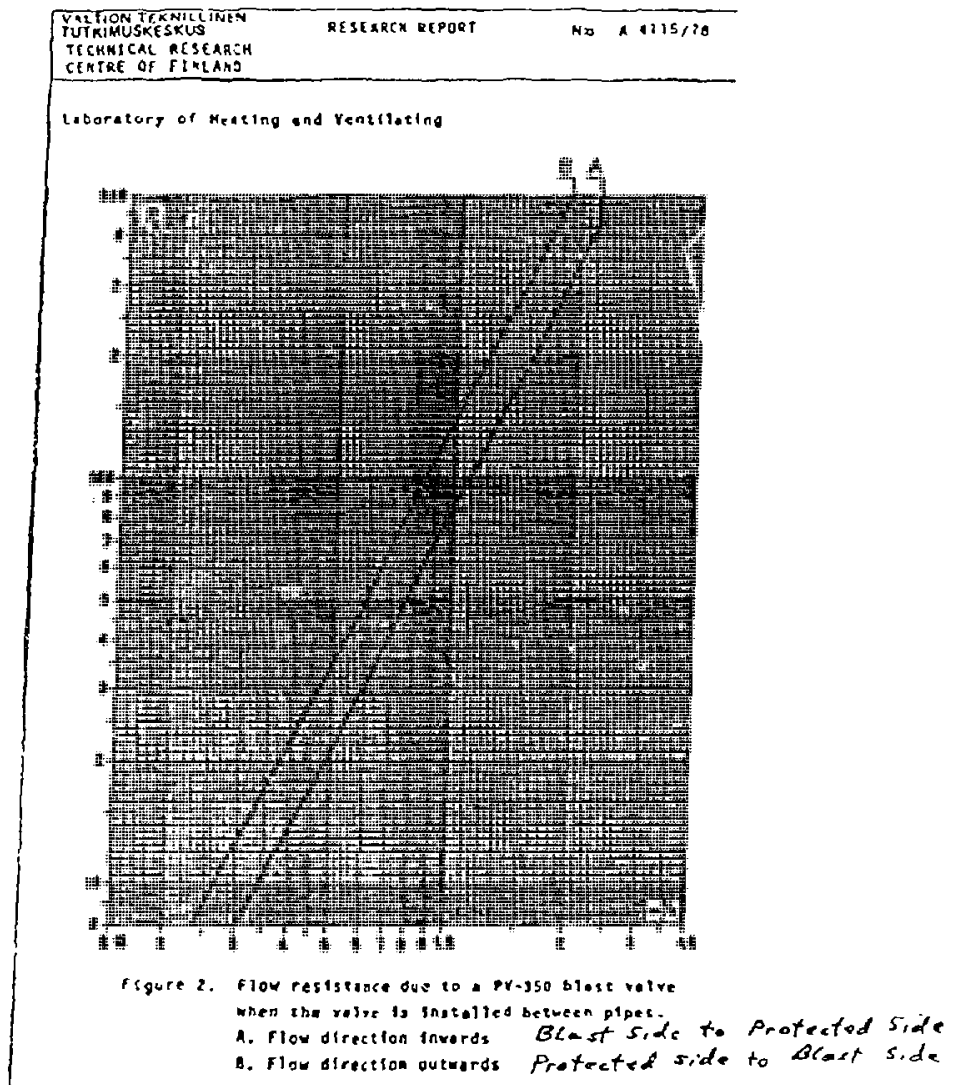

D-

Ficiure 2. Flow resistance for a PV-6-350 blast valve 


\section{Accident Scenarios with Non-Latching Valves}

The reopening of the valve affects the three DBA cases differently, depending on whether the GG would collapse.

\subsection{Case 1 Scenario.}

The sequence of events for Case $1 \mathrm{DBA}$ with latching valve was constructed based on the results of the 1982 test, and discussed in Reference 2. This sequence is modified to account for the reopening of the valve as follows.

- The blast created a gas pressure pulse in the GG, with a peak of $136.2 \mathrm{psi}$ at $0.03 \mathrm{sec}$, according to the 1982 full-scale test.

- The gravel roof began to lift at about $0.1 \mathrm{sec}$, providing a leak path for a brief moment. The pressure in the round room dropped quickly, and the roof fell, closing the path at about $2.25 \mathrm{sec}$.

- The blast also pressurized the staging area (SA) during the first few hundreds msec, but depressurization quickly followed, due to venting through the lifted GG. The pressure in the staging area decreased to po at $0.9 \mathrm{sec}$, at which time the blast valve began opening.

- The roof completed its collapse at about $3.20 \mathrm{sec}$, thus blocking the $7 \mathrm{ft} x$ $8 \mathrm{ft}$ opening between the GG and the stagirg area. This onening, now blocked by gravel, provided an effective leak area of $2.18 \mathrm{ft}^{2}$ from the staging area to the environment.

- The collapse of the roof pushed airborne materials from the GG to the staging area, thus pressurizing it to a peak of $-5 \mathrm{psi}$ at about $3.20 \mathrm{sec}$.

- Following the complete collapse of the GG, venting from the staging area was through the gravel-filled GG-SA opening and the reopened blast valve.

From the pressure data in the GG (1982 test), the valve would have reopened at the time the GG was already depressurized. Then, the GG collapsed shortly thereafter. It was assumed that the additional flow path through the reopened valve was connected to the staging area. The reopened valve would affect the $\mathrm{Pu}$ release to the environment, as well as its transport throughout the DAF buildings. It was also assumed that due to the collapse of the GG, the preaccident ventilation was not re-established in the assembly cell.

\subsection{Case 2 Scenario}

Case 2 accident scenario was similar to that of Case 1 described above, except that the sequence was shorter, and that the valve reopened earlier, at $\mathrm{t}=0.8 \mathrm{sec}$.

\subsection{Case 3 Scenario}

Case 3 involved no GG leak and collapse. Venting was only through the blast doors' leak paths. The pressure in the assembly cell remained high for a 
long time, and the valve did not reopen until $1430 \mathrm{sec}$ following the blast. By contrast with Cases $1 \& 2$, the intact GG remained part of the geometry throughout the calculations. Following the reopening of the valve, the additional release path would strongly affect the Pu behavior throughout the DAF, and the source term. The early phase Pu transport $(t<1430 \mathrm{sec})$, however, would not be affected, and the occupational doses to DAF personnel during this phase would not change.

Becal'se no appreciable damage to the DAF was acsumed in Case 3, the pre-accident ventilation was assumed to re-establish in the assembly cell following the reopening of the valve. This ventilation included infiltration from the personnel and equipment vestibules to the assembly cell, as discussed in 2.1. 


\section{Consequences of DBA-Case 1 with Non-Latching Blast Valves}

This section summarizes the results for the DBA-Case I with non-latching blast valves. Comparison will be made between the effects of latching and nonlatching valves on the $\mathrm{Pu}$ intrafacility transport behavior, on the release to the environment (source term), and on the occupational consequences.

As expected, the additional selease path provided by the reopened valve reduced the Pu contamination of the DAF buildings alcng the corridor. The time behavior of the Pu release to the environment also changed, but contrary to expectations, the total source term did not increase appreciably for this case.

\subsection{Intrafacility Pu Transport}

The Plutonium suspension in various DAF buildings with latching and non-latching valves is compared in Figures 3 through 5 . In the staging area (Figure 3), the pumping action of the collapsing GG, which began about $2 \mathrm{sec}$, caused more release of $\mathrm{Pu}$ to the environment through the reopened valve, thereby depreciating the suspended $\mathrm{Pu}$ in the staging area (SA) during the first few minutes. However, the non-latching valve did not appreciably affect the long-term concentration of suspended $\mathrm{Pu}$ in the SA, because of compensated pressure differential effer.ts: For Case 1, there were several leak paths (roof lift, gravel) beside the reoperied valve. The reopened valve, which accelerated the material flow at first, caused a quicker depressurization and a subsequent slowdown of material release through all leak paths.

The early depletion of suspended Pu in the SA due to the reopened valve, coupled with a quicker depressurization in this area resulted in a decrease in $\mathrm{Pu}$ leaking thirough the blast doors to the personnel and equipment vestibules (Figures $4 \& 5$ ), onto the corridor (Figure 6) and other buildings further away (Figure 7).

\subsection{Release to the Environment (Source Term)}

The source term was first calculated, assuming no filtering effects (unfiltered release). The unfiltered release simply represented the total flow of $\mathrm{Pu}$ into various leak paths. The filtered release was then obtained by using the transmission factors for HEPA filters and gravel. For single stage HEPA filters, this factor was 1.0E-3. For gravel, a transmission factor of $7.29 \mathrm{E}-3$ was estimated in Reference 2.

The components of $\mathrm{Pu}$ unfiltered release through different paths (roof lift, gravel and reopened blast valve) are shown in Figure 8. The release component through other exhaust paths along the corridor was too small ( $3.3 \mathrm{E}-2 \mathrm{gm}$ total) to be shown in the Figure. The roof lift release was terminated very early in the accident, before the valve reopened, and was independent of the blast valve behavior. Although the flow of $\mathrm{Pu}$ through the reopened valve began as early as $0.9 \mathrm{sec}$, and the flow through the gravel-filled GG-SA opening did not begin until after $3.0 \mathrm{sec}$ into the accident, there was more Pu flowing through the gravel than 


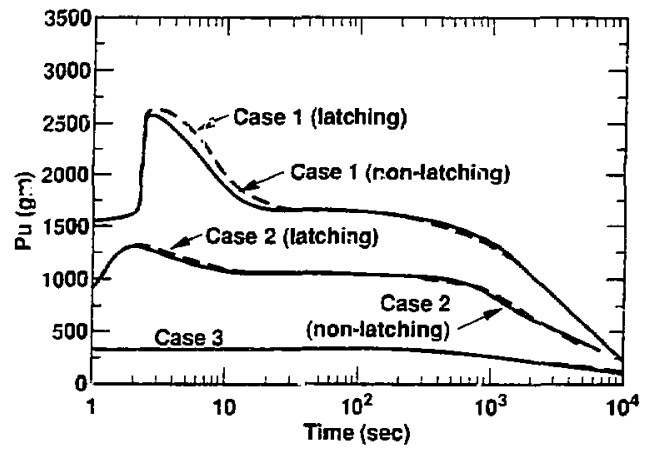

Figure 3. Suspended Pu in staging area: Comparison of various accident cases with latching and non-latching valve. 


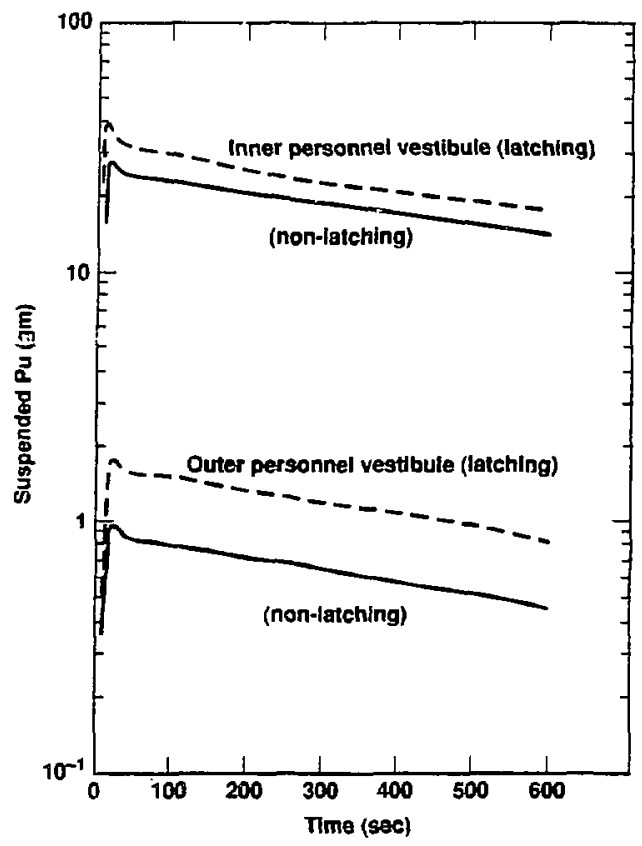

Fgurs 4. Suspendesi Pu in personnel vestibules: Compartson of behavior whth latching and non-latching valve. Caso 1: 423\#HE, $16 \mathrm{~kg}$ Pu 


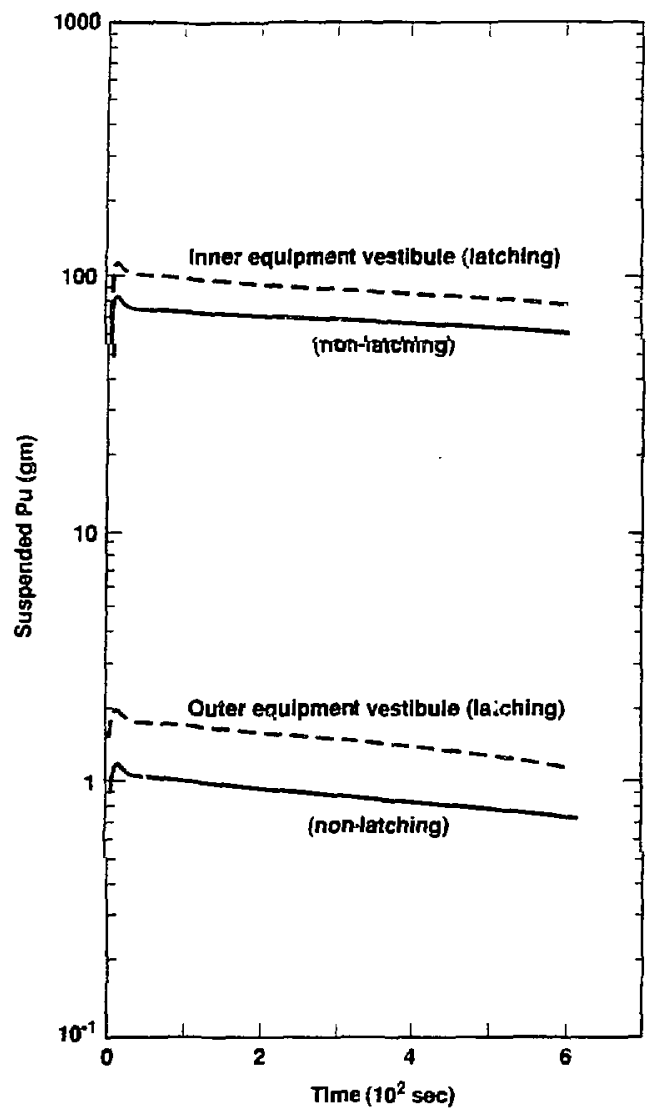

Figure 5. Suspended Pu in equlpment vestibules: Comparison of behavlor with latching and non-latening valve. Casa 1: 423*HE, $16 \mathrm{~kg} \mathrm{Pu}$ 


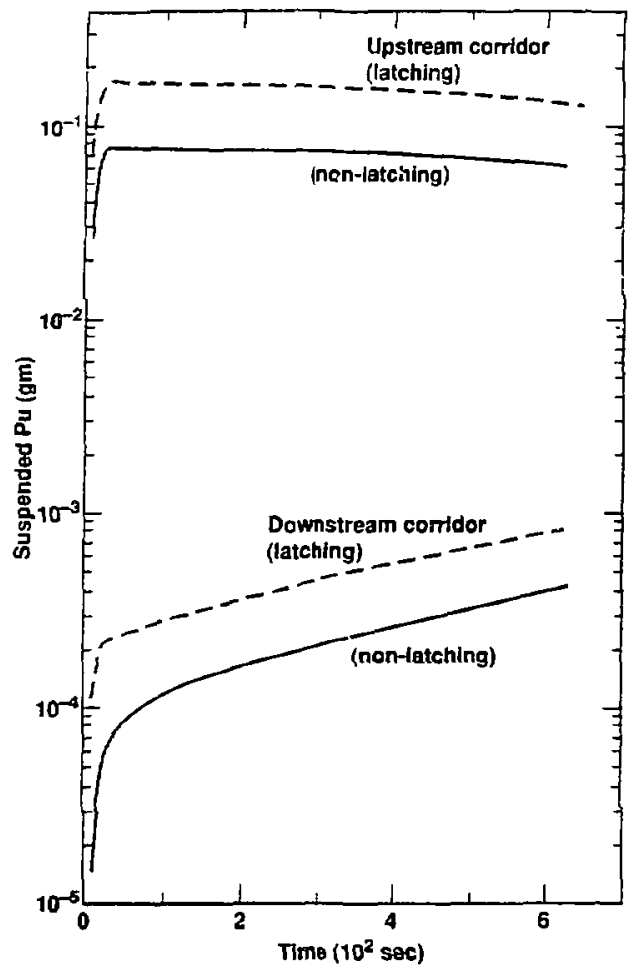

Flgure 6. Suspended Pu in corridor: Comparison of behavlor with iatching and non-latching valvo.

Case 1: d234HE, $16 \mathrm{~kg} \mathrm{Pu}$ 


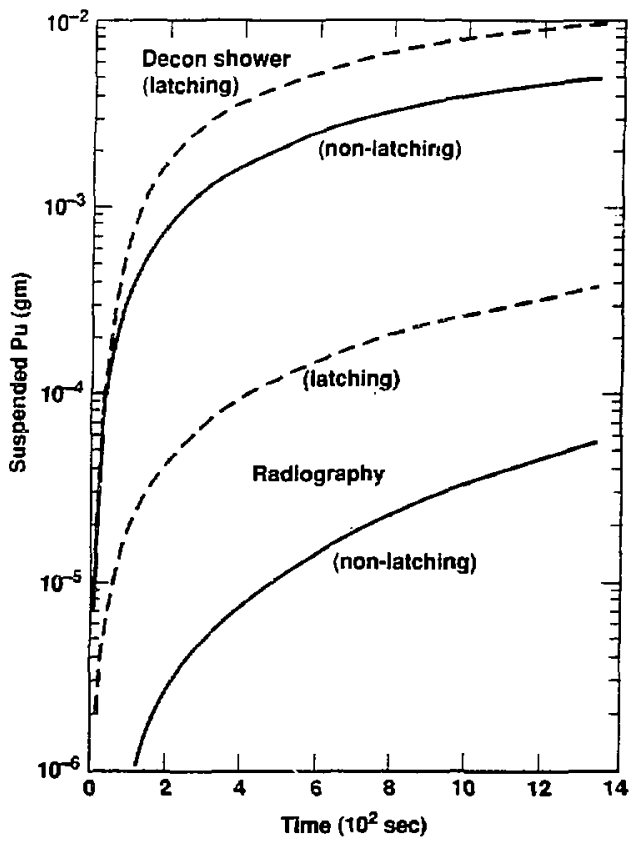

Figure 7. Suspendad Pu In Decon room and radlography bullding: Comparison of behavior with fatching and non-latching valve. Case 1: 423:HE, $16 \mathrm{~kg} \mathrm{Pu}$ 


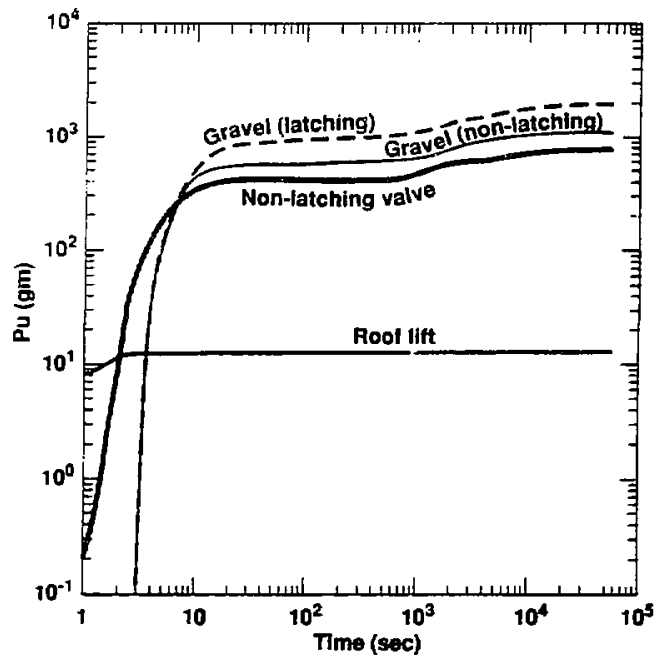

Figure 8. Components of unfiltered source term: Poof litt, non-latching valve and gravel (latching and non-letching) - Case 1: 423 $\mathrm{kHE}, 16 \mathrm{~kg} \mathrm{Pu}$ 
through the opened valve. Th s was because the effective flow area through the gravel was larger than that of the opened valve. However, with the additional flow area of the opened valve, less Pu flowed through the gravel compared to the case with a latching valve.

The total unfiltered and filtered releases are listed in Table 2, and shown in Figure 9. Although as expected, the Pu flow throligh various release paths (the unfiltered release) was higher with a non-latching valve than with a latching one, the increase was surprisingly small $(1.823 \mathrm{~kg}$ vs. $1.801 \mathrm{~kg})$. As discussed earlier, this trend was the result of a compensation effect between an early increase in $\mathrm{Pu}$ release when the valve reopened, followed by a faster depressurization and a flow decrease through the leak paths.

The non-latching valve could reduce the total filtered release, however. (Figure $9,8.69 \mathrm{gm}$ vs. $13.13 \mathrm{gm}$ ). This was because with the non-latching valve, part of the Pu that flowed through gravel in the latching case now passed through the opened valve duct equipped with HEPA filters which had a higher filtering efficiency.

In sumrary, aithough the total Pu mass flowing through various release paths was higher with the non-latching valve, the actual iotal source term may be less compared to the latching case, because of the higher filtering efficiency of the HEPA filters compared to gravel. However, it should be noted that a total of $735.2 \mathrm{gm}$ Fu was loading the HEPA filters downstream from the non-latching valve, and the integrity of the filters should be assessed.

\subsection{Occupational Consequences to DAF Personnel}

Tables 3 through 6 compare the lung doses and the Effective Whole Body Dose Equivalent (EWBDE) for the DAF personnel in various buildings (corridor, decon room and radiography). These tables show the doses for the first three minutes following the blast, with the first minute composed of three 20-sec intervals. The second and third columns show the Pu mass inhaled ( $\mu \mathrm{g})$, and doses received (rem), respectively, corresponding to the time interval shown in the first column. For comparison purpose, the values with latching valves are shown in parentheses. For example, from Table 3, a worker walking in the corridor just outside the assembly cell (upstream corridor), and with a 20 liter / min respiration rate, would inhale $0.106 \mu \mathrm{g} \mathrm{Pu}$ during the first $20 \mathrm{sec}$, resulting in a 50-year committed lung dose of 10.6 rem and EWBDE dose of 2.9 rem. By comparison, with a latching valve, he would have inhaled $0.118 \mu \mathrm{g} \mathrm{Pu}$, resulting in $11.8 \mathrm{rem}$ lung dose and $3.3 \mathrm{rem}$ EWBDE dose. The Pu concentration in the corridor increased at first, being pushed through the leak path of the blast doors, so that the worker would receive higher doses during the second 20 -sec interval. Then, the suspended Pu concentration began to decrease during the third 20-sec interval, and the doses in this interval decreased accordingly. By contrast, the build-up of Pu in other buildings still increased during the first three minutes, and so were the associated doses (Tables 4 ihrough 6). From Figures $6 \& 7$, the build-up of Pu in buildings away from the assembly cell (downstream corridor, radiography, high bay) would continue for an extended 
time (order of an hour), so that workers remaining in these buildings would continue to receive doses at higher rates during the first hour or so.

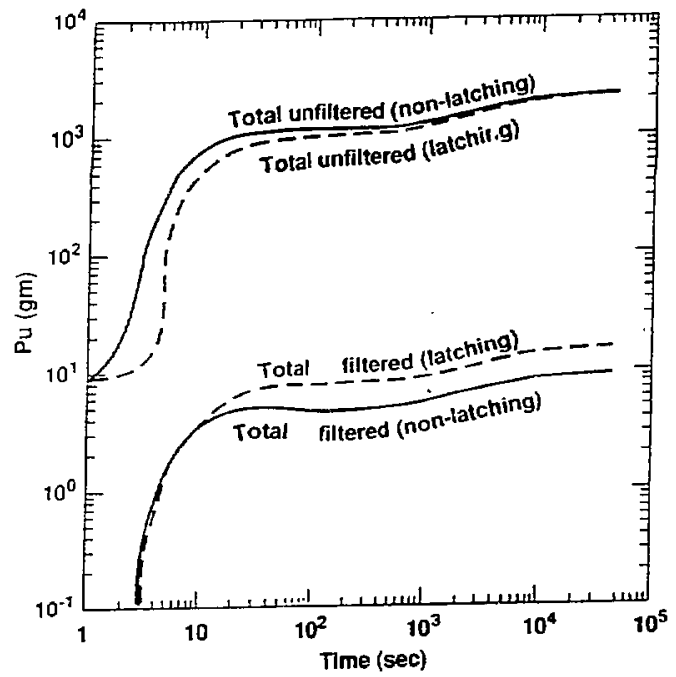

Figure 9. Total source term (Pu release to environment): Comparison between filtered and unfiltered release, with latching and non-latching valve.

- Case 1: 423*HE, $16 \mathrm{~kg} \mathrm{Pu}$ 
Table 2

Source Term from DAF Design-Basis-Accident - Case 1 (423\#HE, $16 \mathrm{~kg} \mathrm{Pu}$ ) (Cumulative release to environment)

\begin{tabular}{|c|c|c|c|c|}
\hline \multirow[t]{2}{*}{ Time(sec) } & \multicolumn{2}{|c|}{ Unfiltered Release(kg Pu) } & \multicolumn{2}{|c|}{ Filtered Release(kg Pu) } \\
\hline & latching & non-latching & latching & non-latching \\
\hline 1 & $8.645 e-3$ & $8.645 e-3$ & $6.302 e-5$ & $6.320 \mathrm{e}-5$ \\
\hline 2 & $1.087 \mathrm{e}-2$ & $1.661 \mathrm{e}-2$ & $7.920 \mathrm{e}-5$ & $8.500 \mathrm{e}-5$ \\
\hline 3 & $1.280 \mathrm{e}-2$ & $7.173 e-2$ & $9.330 e-5$ & $1.520 \mathrm{e}^{-4}$ \\
\hline 5 & 0.1463 & 0.3029 & $1.070 \mathrm{e}-3$ & $1.153 \mathrm{e}-3$ \\
\hline 10 & 0.4994 & 0.7263 & $3.640 \mathrm{e}-3$ & $3.260 \mathrm{e}-3$ \\
\hline 15 & 0.7049 & 0.8897 & $5.140 \mathrm{e}-3$ & $4.010 \mathrm{e}-3$ \\
\hline 20 & 0.8192 & 0.9261 & $5.970 \mathrm{e}-3$ & $4.270 \mathrm{e}-3$ \\
\hline 30 & 0.8802 & 0.9349 & $6.420 \mathrm{e}-3$ & $4.300 \mathrm{e}-3$ \\
\hline 40 & 0.8882 & 0.9382 & $6.470 e-3$ & $4.350 \mathrm{e}-3$ \\
\hline 50 & 0.8922 & 0.9414 & $6.500 \mathrm{e}-3$ & $4.365 e-3$ \\
\hline 80 & 0.9055 & 0.9503 & $6.600 \mathrm{e}-3$ & $4.390 \mathrm{e}-3$ \\
\hline 110 & 0.9177 & $0 . \dot{9} 586$ & $6.690 \mathrm{e}-3$ & $4.490 \mathrm{e}-3$ \\
\hline 240 & 0.9595 & 0.9900 & $6.994 e-3$ & $4.590 \mathrm{e}-3$ \\
\hline 440 & 1.007 & 1.0297 & $7.340 \mathrm{e}-3$ & $4.790 \mathrm{e}-3$ \\
\hline 890 & 1.0841 & 1.0998 & $7.900 \mathrm{e}-3$ & $5.090 e-3$ \\
\hline 1240 & 1.1298 & 1.1438 & $8.240 \mathrm{e}-3$ & $5.390 \mathrm{e}-3$ \\
\hline 2000 & 1.3147 & 1.3306 & $9.580 \mathrm{e}-3$ & $6.290 \mathrm{e}-3$ \\
\hline 5000 & 1.5141 & 1.5310 & $1.164 \mathrm{e}-2$ & $7.270 \mathrm{e}-3$ \\
\hline 10000 & 1.6928 & 1.7192 & $1.234 \mathrm{e}-2$ & $8.190 \mathrm{e}-3$ \\
\hline 20000 & 1.7840 & 1.8055 & $1.300 \mathrm{e}-2$ & $8.590 \mathrm{e}-3$ \\
\hline 30000 & 1.8012 & 1.8230 & $1.313 \mathrm{e}-2$ & $8.690 \mathrm{e}-3$ \\
\hline
\end{tabular}


Table 3

50-year committed doses in upstream corridor (respiration at $20 \mathrm{l} / \mathrm{min}$ ) Comparison between consequences with latching (in parentheses) and non-latching valve for Case 1 (423\# HE, $16 \mathrm{~kg} P$

\begin{tabular}{|c|c|c|c|c|c|}
\hline \multirow{2}{*}{$\begin{array}{l}\text { Time } \\
\text { duration }\end{array}$} & \multirow{2}{*}{$\begin{array}{l}\text { Mass innaled } \\
(\mu g)\end{array}$} & \multicolumn{2}{|c|}{ Doses' $\mathrm{em}$} & \multicolumn{2}{|c|}{$\begin{array}{l}\text { Cumulative doses } \\
\text { (rem) }\end{array}$} \\
\hline & & Lung & EWBDE & L.ung & EWBDE \\
\hline $20 \mathrm{sec}$ & $0.106(0.118)$ & $10.6(11.8)$ & $2.9(3.3)$ & & \\
\hline $20 \mathrm{sec}$ & $0.374(0.883)$ & $37.5(88.6)$ & $10.5(24.7)$ & & \\
\hline $20 \mathrm{sec}$ & $0.373(0.879)$ & $37.4(88.2)$ & $10.4(24.6)$ & $85.6(188.6)$ & $23.8(52.6)$ \\
\hline $1 \mathrm{~min}$ & $1.11(2.60)$ & $111.4(260.3)$ & $31.0(72.6)$ & $197.0(448.6)$ & $54.8(125.2)$ \\
\hline $1 \mathrm{~min}$ & $1.09(2.58)$ & I09.8(259.0) & $30.6(72.1)$ & $306.8(707.6)$ & $85.4(197.3)$ \\
\hline
\end{tabular}

Table 4

50-year committed doses in dow'nstream corridor (respiration at $201 / \mathrm{min}$ )Comparis sn between consequences with latching (in parentheses) and non-latching valve for Case 1 (423\# HE, $16 \mathrm{~kg} \mathrm{Pu}$ )

\begin{tabular}{|c|c|c|c|c|c|}
\hline \multirow{2}{*}{$\begin{array}{c}\text { Time } \\
\text { duration }\end{array}$} & \multirow{2}{*}{$\begin{array}{l}\text { Mass inhaled } \\
(\mu g)\end{array}$} & \multicolumn{2}{|c|}{ Doses(rem) } & \multicolumn{2}{|c|}{$\begin{array}{c}\text { Cumulative doses } \\
\text { (rem) }\end{array}$} \\
\hline & & Lung & EWBDE & Lung & $\mathrm{EWBDE}$ \\
\hline $20 \mathrm{sec}$ & $9.00 e-5(1.07 e-4)$ & $9.03 e-3(1.12 e-2)$ & $.0025(.003)$ & & \\
\hline $20 \mathrm{sec}$ & $4.89 \mathrm{e}-4(1.46 \mathrm{e}-3)$ & $4.91 \mathrm{e}-2(1.46 \mathrm{e}-1)$ & $.014(.041)$ & & \\
\hline $20 \mathrm{sec}$ & $5.66 e-4(1.57 e-3)$ & $5.68 \mathrm{e}-2(1.57 \mathrm{e}-1)$ & $.016(.044)$ & $.115(.314)$ & $.03(.088)$ \\
\hline $1 \mathrm{~min}$ & $2.04-3(5.3 e-3)$ & $.205(.532)$ & $.057(.148)$ & $.320(.846)$ & $.09(.236)$ \\
\hline $1 \mathrm{~min}$ & $2.70 \mathrm{e}-3(6.2 \mathrm{e}-3)$ & $.271(.622)$ & $.075(.173)$ & $.591(1.47)$ & $.164(.409)$ \\
\hline
\end{tabular}


Table 5

50-year committed doses in decon room (respiration at $201 / \mathrm{min}$ )Comparison between consequences with latching (in parentheses) and non-latching valve for Case 1 ( $423 \# \mathrm{HE}, 16 \mathrm{~kg} \mathrm{Pu})$

\begin{tabular}{|c|c|c|c|c|c|}
\hline \multirow{2}{*}{$\begin{array}{c}\text { Time } \\
\text { duration }\end{array}$} & \multirow{2}{*}{$\begin{array}{l}\text { Mass inhaled } \\
(\mu g)\end{array}$} & \multicolumn{2}{|c|}{ Doses(rem) } & \multicolumn{2}{|c|}{$\begin{array}{c}\text { Cumulative doses } \\
\text { (rem) }\end{array}$} \\
\hline & & Lung & EWBDE & Lung & EWBDE \\
\hline $20 \mathrm{sec}$ & $1.98 \mathrm{e}-4(2.18 \mathrm{e}-4)$ & $.020(.022)$ & $.0055(.006)$ & & \\
\hline $20 \mathrm{sec}$ & $3.20 \mathrm{e}-3(6.27 \mathrm{e}-3)$ & $.321(629)$ & $.089(.175)$ & & \\
\hline $20 \mathrm{sec}$ & $6.52 e-3(1.41 e-2)$ & $.654(1.415)$ & $.182(.394)$ & $1.00(2.07)$ & $.28(.58)$ \\
\hline $1 \mathrm{~min}$ & $3.42 e-2(9.00 e-2)$ & $3.43(9.03)$ & $.956(2.51)$ & $4.43(11.1)$ & $1.23(3.09)$ \\
\hline $1 \mathrm{~min}$ & $6.24 e-2(1.54 e-1)$ & $6.26(15.45)$ & $1.74(4.30)$ & $10.59 / 26.55)$ & $2.97(7.40)$ \\
\hline
\end{tabular}

Table 6

50-year committed doses in radiography building (respiration at $20 \mathrm{l} / \mathrm{min}$ )Comparison between consequences with latching (in parentheses) and non-latching valve for Case 1 (423\# HE, $16 \mathrm{~kg} \mathrm{Pu}$ )

\begin{tabular}{|c|c|c|c|c|c|}
\hline \multirow{2}{*}{$\begin{array}{c}\text { Time } \\
\text { duration }\end{array}$} & \multirow{2}{*}{$\begin{array}{l}\text { Mass inhaled } \\
(\mu g)\end{array}$} & \multicolumn{2}{|c|}{ Doses(rem) } & \multicolumn{2}{|c|}{$\begin{array}{c}\text { Cumulative doses } \\
\text { (rem) }\end{array}$} \\
\hline & & Lung & EWBDE & Lung & EWBDE \\
\hline $20 \mathrm{sec}$ & $1.35 e-7(1.79 e-6)$ & $1.35 e-5(1.79 e-4)$ & $3.77 e-6(5.0 e-5)$ & & \\
\hline $20 \mathrm{sec}$ & $9.23 e-7(1.92 e-5)$ & $9.26 e^{-5}(1.93 e-3)$ & $2.58 e-5(5.4 e-4)$ & & \\
\hline $20 \mathrm{sec}$ & $1.94 e-6(4.02 e-5)$ & $1.95 e-4(4.04 e-3)$ & $5.42 e-5(1.12 e-3)$ & $\begin{array}{l}.0003 \\
(.006)\end{array}$ & $\begin{array}{l}8.38 e-5 \\
(2.0 e-3)\end{array}$ \\
\hline $1 \mathrm{~min}$ & $1.1 e-5(2.40 e-4)$ & $1.10 e-3(2.40 e-2)$ & $3.07 e-4(6.7 e-3)$ & $\begin{array}{l}.0014 \\
(.03)\end{array}$ & $\begin{array}{l}3.91 \mathrm{e}-4 \\
(8.0 \mathrm{e}-3)\end{array}$ \\
\hline $1 \mathrm{~min}$ & $2.32 e-5(4.46 e-4)$ & $2.33 e-3(4.50 e-2)$ & $6.48 e-4(1.25 e-2)$ & $\begin{array}{l}.0037 \\
(.075)\end{array}$ & $\begin{array}{l}1.04 \mathrm{e}-3 \\
(2.1 \mathrm{e}-2)\end{array}$ \\
\hline
\end{tabular}




\section{Consequences of DBA-Case 2 with Non-Latching Blast Valves}

Although involving less $\mathrm{HE}$, the blast in Case 2 was sufficient to lift the GG. The dynamics of Case 2 were similar to those of Case 1, except for the timing. Because of a less intense blast, the valve reopened at an earlier time ( 0.8 sec for Case 2 compared to $0.9 \mathrm{sec}$ for Case 1).

The build-up of suspended $\mathrm{Pu}$ in the corridor and in other buildings is shown in Figures 10 and 11, respectively. A similar behavior is observed between Cases $1 \& 2$, with less Pu build-up in non-latching case than in latching case. However, with non-latching valves, the Pu build-up in the downstream corridor (Figure 10) and in the decontamination shower (Figure 11) reached the peak much sooner for Case 2 than for Case 1 (Compare Figures 10 \& 11 with Figures 6 \& 7 , respectively).

The unfiltered and filtered source terms (release to the environment) behaved in a similar way to Case 1, except for smaller amounts of Pu in Case 2 (Compare Figures $12 \& 13$ to Figures $8 \& 9$, respectively). These source terms are also listed in Table 7. For Case 2, the total unfiltered source term was $838.6 \mathrm{gm}$ for the non-latching case and $828.2 \mathrm{gm}$ for the latching ca\%o. By contrast, the filtered source term was $4.05 \mathrm{gm}$ for the non-latching cas a compared to $6.04 \mathrm{gm}$ for the latching case. Like Case 1, the lower filtered source term for the nonlatching case was due to the higher filtering efficiency of the HEPA filter downstream from the valve. For Case 2, these filters received a loading of $328 \mathrm{gm}$ $\mathrm{Pu}$.

The 50-year committed doses in the corridor, decon room, and radiography building, with latching and non-latching valves are compared in Tables 8 through 11 . 


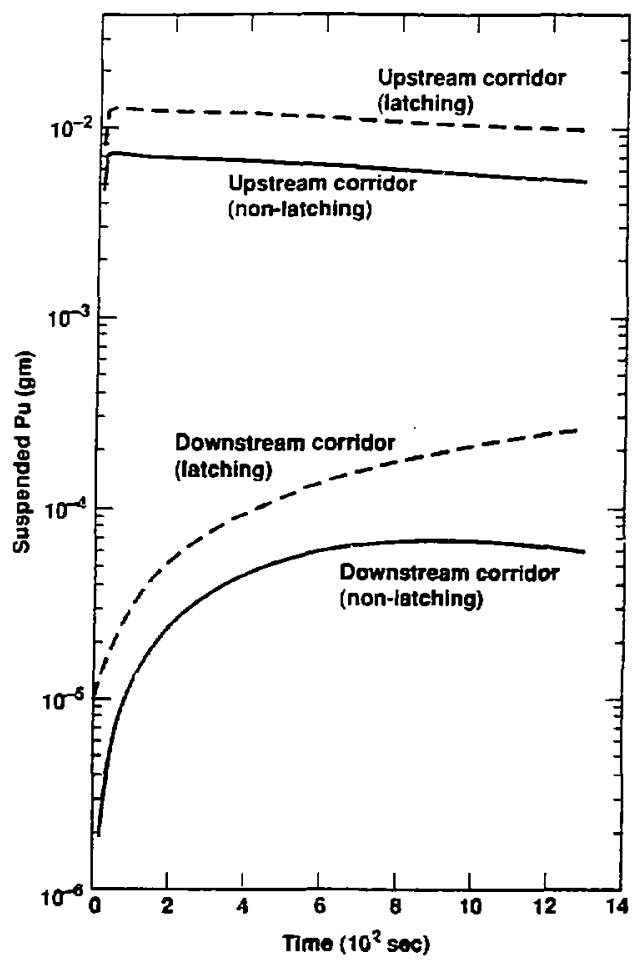

Flgure 10. Suspended Pu In cortider: Comparison of behavior with latching and non-latehing vajvo. Case 2: 150.HE, $10 \mathrm{~kg}$ Pu 


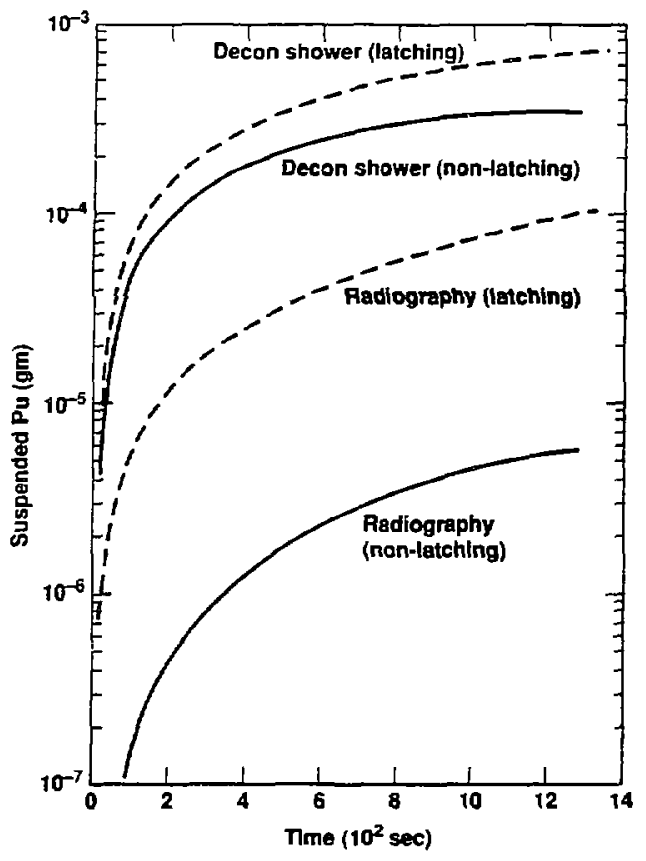

Fgure 1t. Suspended Pu in Oscon room and radlograpty bullding: Comparison of behavior with Jatching and nor-latching vaive. Case 2: 150:HE, $10 \mathrm{~kg} \mathrm{Pu}$ 


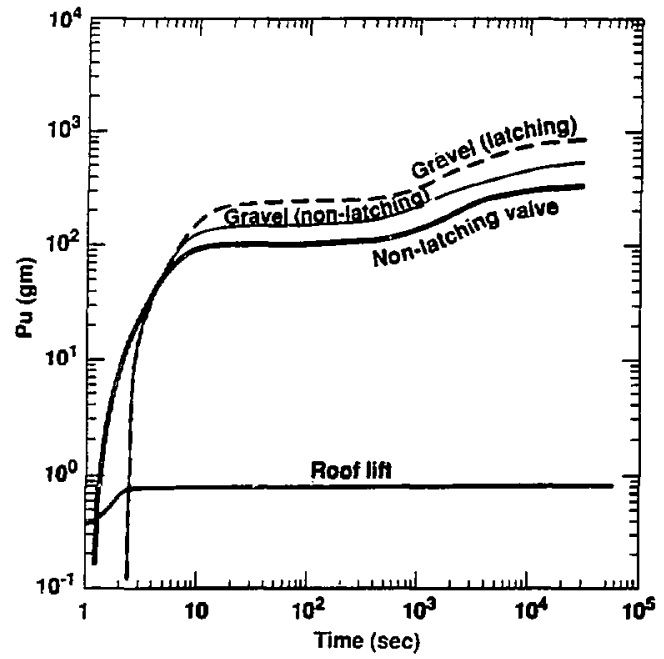

Figure 12 components of unfiltered source term: Roof lift, non-latching valve and gravel (latehing and non-latching) - Case 2: 150wHE, $10 \mathrm{~kg} \mathrm{Pu}$ 


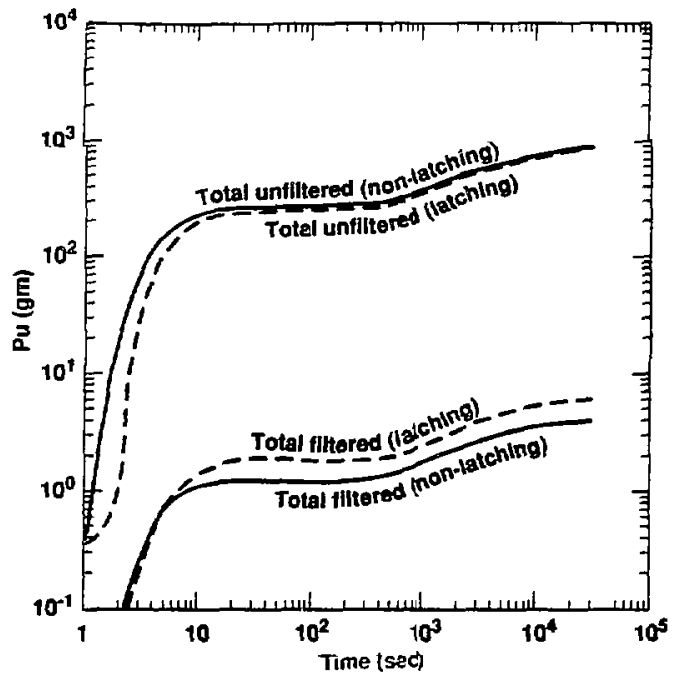

Figure 13. Total source term (Pu release to environmem): Comparison between filtered and unfiltered releses, with latching and non-latching valve.

- Cace 2: 150:HE, $10 \mathrm{~kg}$ Pu 
Table 7

Source Term from DAF Design-Basis-Accident - Case 2(150\#HE, $10 \mathrm{~kg} \mathrm{Pu}$ ) (Cumulative release to environment)

\begin{tabular}{rllll}
\hline Time(sec) & \multicolumn{2}{c}{$\begin{array}{c}\text { Unfiltered Release(kg Pu) } \\
\text { latching }\end{array}$} & & \multicolumn{2}{c}{$\begin{array}{c}\text { Filtered Release(kg Pu) } \\
\text { latching }\end{array}$} & \\
& & & & \\
non-latching & & & \\
1 & $3.620 \mathrm{e}-4$ & $3.620 \mathrm{e}-4$ & $2.640 \mathrm{e}-6$ & $2.640 \mathrm{e}-6$ \\
2 & $7.853 \mathrm{e}-4$ & $1.560 \mathrm{e}-2$ & $5.725 \mathrm{e}-6$ & $2.052 \mathrm{e}-5$ \\
3 & $2.640 \mathrm{e}-2$ & $6.060 \mathrm{e}-2$ & $1.923 \mathrm{e}-4$ & $2.174 \mathrm{e}-4$ \\
5 & 0.09 & 0.1462 & $6.560 \mathrm{e}-4$ & $6.447 \mathrm{e}-4$ \\
10 & 0.1864 & 0.2356 & $1.360 \mathrm{e}-3$ & $1.094 \mathrm{e}-3$ \\
15 & & 0.2490 & & $1.169 \mathrm{e}-3$ \\
20 & 0.2382 & 0.2508 & $1.736 \mathrm{e}-3$ & $1.179 \mathrm{e}-3$ \\
30 & 0.2393 & 0.2521 & $1.745 \mathrm{e}-3$ & $1.190 \mathrm{e}-3$ \\
50 & 0.2414 & 0.2538 & $1.760 \mathrm{e}-3$ & $1.200 \mathrm{e}-3$ \\
80 & 0.2445 & 0.2564 & $1.783 \mathrm{e}-3$ & $1.214 \mathrm{e}-3$ \\
140 & 0.2503 & 0.2615 & $1.825 \mathrm{e}-3$ & $1.240 \mathrm{e}-3$ \\
340 & 0.2682 & 0.2777 & $1.955 \mathrm{e}-3$ & $1.320 \mathrm{e}-3$ \\
540 & 0.2844 & 0.2933 & $2.073 \mathrm{e}-3$ & $1.397 \mathrm{e}-3$ \\
890 & 0.3108 & 0.3319 & $2.266 \mathrm{e}-3$ & $1.588 \mathrm{e}-3$ \\
1240 & 0.3830 & 0.4190 & $2.792 \mathrm{e}-3$ & $2.022 \mathrm{e}-3$ \\
2000 & 0.4842 & 0.5061 & $3.530 \mathrm{e}-3$ & $2.455 \mathrm{e}-3$ \\
5000 & 0.6348 & 0.6455 & $4.628 \mathrm{e}-3$ & $3.133 \mathrm{e}-3$ \\
10000 & 0.7431 & 0.7538 & $5.417 \mathrm{e}-3$ & $3.652 \mathrm{e}-3$ \\
20000 & 0.8088 & 0.8190 & $5.896 \mathrm{e}-3$ & $3.955 \mathrm{e}-3$ \\
30000 & 0.8282 & 0.8386 & $6.038 \mathrm{e}-3$ & $4.050 \mathrm{e}-3$ \\
\hline
\end{tabular}


Table 8

50-year committed doses in upstream corridor (respiration at $201 / \mathrm{min}$ ) -

Comparison between consequences with latching (in parentheses) and non-latching valve for Case 2 (150\# $\mathrm{HE}, 10 \mathrm{~kg} \mathrm{Pu}$ )

\begin{tabular}{|c|c|c|c|c|c|}
\hline \multirow{2}{*}{$\begin{array}{c}\text { Time } \\
\text { duration }\end{array}$} & \multirow{2}{*}{$\begin{array}{l}\text { Mass inhaled } \\
(\mu g)\end{array}$} & \multicolumn{2}{|c|}{ Doses $(\mathrm{rem})$} & \multicolumn{2}{|c|}{$\begin{array}{c}\text { Cumulative doses } \\
\text { (rem) }\end{array}$} \\
\hline & & Lung & EWBDE & Lung & EWBDE \\
\hline $20 \mathrm{sec}$ & $.0246(.0438)$ & $2.47(4.39)$ & $.687(1.22)$ & & \\
\hline $20 \mathrm{sec}$ & $.0353(.0633)$ & $3.54(6.35)$ & $.986(1.77)$ & & \\
\hline $20 \mathrm{sec}$ & $.0351(.0630)$ & $3.52(6.32)$ & $.981(1.76)$ & $9.53(17.06)$ & $2.65(4.75)$ \\
\hline $1 \mathrm{~min}$ & $.105(.188)$ & $10.54(18.86)$ & $2.93(5.25)$ & $20.07(35.92)$ & $5.59(10.0)$ \\
\hline $1 \mathrm{~min}$ & $.103(.185)$ & $10.34(18.56)$ & $2.88(5.17)$ & $30.41(54.48)$ & $8.47(15.17)$ \\
\hline
\end{tabular}

Table 9

50-year committed doses in downstream corridor (respiration at $201 / \mathrm{min}$ ) Comparison between consequences with latching (in parentheses) and non-latching valve for Case 2 (150\# $\mathrm{HE}, 10 \mathrm{~kg} \mathrm{Pu}$ )

\begin{tabular}{|c|c|c|c|c|c|}
\hline \multirow{2}{*}{$\begin{array}{c}\text { Time } \\
\text { duration }\end{array}$} & \multirow{2}{*}{$\begin{array}{l}\text { Mass inhaled } \\
(\mu \mathrm{g})\end{array}$} & \multicolumn{2}{|c|}{ Doses(rem) } & \multicolumn{2}{|c|}{$\begin{array}{c}\text { Cumulative doses } \\
\text { (rem) }\end{array}$} \\
\hline & & Lung & EWBDE & Lung & EWBDE \\
\hline $20 \mathrm{sec}$ & $1.66 e-5(2.46 e-5)$ & $1.67 e-3(2.47 e-3)$ & $4.64 e-4(6.87 e-4)$ & & \\
\hline $20 \mathrm{sec}$ & $3.85 e-5(8.35 e-5)$ & $3.86 e-3(8.38 e-3)$ & $1.09 e-3(2.33 e-3)$ & & \\
\hline $20 \mathrm{sec}$ & $5.27 e-5(1.13 e-4)$ & $5.29 e-3(1.13 e-2)$ & $1.47 e-3(3.14 e-3)$ & $\begin{array}{l}.0108 \\
(.0222)\end{array}$ & $\begin{array}{l}.003 \\
(.0062)\end{array}$ \\
\hline $1 \mathrm{~min}$ & $2.22 e-4(5.2 e-4)$ & $2.23 e-2(5.22 e-2)$ & $0062(.0145)$ & $\begin{array}{l}.033 \\
(.074)\end{array}$ & $\begin{array}{l}.0092 \\
(.021)\end{array}$ \\
\hline $1 \mathrm{~min}$ & $3.48 e-4(8.0 e-4)$ & $3.49 e-2(8.02 e-2)$ & $.0097(.0224)$ & $\begin{array}{l}.068 \\
(.155)\end{array}$ & $\begin{array}{l}.0193 \\
(.043)\end{array}$ \\
\hline
\end{tabular}


Table 10

50-year committed doses in Decon room (respiration at $20 \mathrm{l} / \mathrm{min}$ ) Comparison between consequences with latching (in parentheses) and non-latching valve for Case 2 (150\# $\mathrm{HE}, 10 \mathrm{~kg} \mathrm{Pu}$ )

\begin{tabular}{|c|c|c|c|c|c|}
\hline \multirow{2}{*}{$\begin{array}{l}\text { Time } \\
\text { duration }\end{array}$} & \multirow{2}{*}{$\begin{array}{l}\text { Mass inhaled } \\
(\mu \mathrm{g})\end{array}$} & \multicolumn{2}{|c|}{ Doses(rem) } & \multicolumn{2}{|c|}{$\begin{array}{c}\text { Cumulative doses } \\
\text { (rem) }\end{array}$} \\
\hline & & Lung & EWBDE & Lung & EWBDE \\
\hline $20 \mathrm{sec}$ & $5.33 e-5(6.58 e-5)$ & $5.35 e-3(6.60 e-3)$ & $1.49 e-3(1.84 e-3)$ & & \\
\hline $20 \mathrm{sec}$ & $3.66 e-4(6.07 e-4)$ & $3.67 e-2(6.09 e-2)$ & $1.02 \mathrm{e}-2(1.70 \mathrm{e}-2)$ & & \\
\hline $20 \mathrm{sec}$ & $6.78 \mathrm{e}-4(1.17 \mathrm{e}-3)$ & $6.80 e-2(1.17 e-1)$ & $1.89 e-2(3.30 e-2)$ & $.11(.185)$ & $.031(.052)$ \\
\hline $1 \mathrm{~min}$ & $3.41 \mathrm{e}-3(6.60 \mathrm{e}-3)$ & $.342(.662)$ & $.095(.184)$ & $.452(.847)$ & $.126(.236)$ \\
\hline $1 \mathrm{~min}$ & $6.06 \mathrm{e}-3(1.14 \mathrm{e}-2)$ & $.608(1.14)$ & $.169(.320)$ & $1.06(1.99)$ & $.295(.556)$ \\
\hline
\end{tabular}

Table 11

50-year committed doses in radiography building(respiration at $20 \mathrm{l} / \mathrm{min}$ ) -

Comparison between consequences with latching (in parentheses) and non-latching valve for Case 2 (150\# $\mathrm{HE}, 10 \mathrm{~kg} \mathrm{Pu}$ )

\begin{tabular}{|c|c|c|c|}
\hline \multirow{2}{*}{$\begin{array}{c}\text { Time } \\
\text { duration }\end{array}$} & \multirow{2}{*}{$\begin{array}{c}\text { Mass inhaled } \\
(\mu g)\end{array}$} & Doses(rem) & $\begin{array}{c}\text { Cumulative doses } \\
\text { (rem) }\end{array}$ \\
\hline & & EWBDE & EWBDE \\
\hline
\end{tabular}

$20 \mathrm{sec} \quad 1.06 \mathrm{e}-8(8.57 \mathrm{e}-7) \quad 1.07 \mathrm{e}-6(8.60 \mathrm{e}-5) \quad 2.97 \mathrm{e}-7(2.39 \mathrm{e}-5)$

$20 \mathrm{sec} \quad 6.97 \mathrm{e}-8(5.86 \mathrm{e}-6) \quad 6.99 \mathrm{e}-6(5.88 \mathrm{e}-4) \quad 1.95 \mathrm{e}-6(1.64 \mathrm{e}-4)$

$20 \mathrm{sec} \quad 1.49 \mathrm{e}-7(1.11 \mathrm{e}-5) \quad 1.50 \mathrm{e}-5(1.11 \mathrm{e}-3) \quad 4.17 \mathrm{e}-6(3.10 \mathrm{e}-4) \quad 2.30 \mathrm{e}-5 \quad 6.42 \mathrm{e}-6$

$1 \mathrm{~min} \quad 9.17 \mathrm{e}-7(6.40 \mathrm{e}-5) \quad 9.20 \mathrm{e}-5(6.42 \mathrm{e}-3) 2.56 \mathrm{e}-5(1.79 \mathrm{e}-3) \quad 1.15 \mathrm{e}-4 \quad 3.20 \mathrm{e}-5$

$(8.20 \mathrm{e}-3) \quad(2.29 \mathrm{e}-3)$

$1 \mathrm{~min} \quad 2.25 e-6(1.14 e-4) \quad 2.26 e-4(1.14 e-2) \quad 6.29 e-5(3.20 \mathrm{e}-3) \quad 3.41 \mathrm{e}-4 \quad 9.50 \mathrm{e}-5$

$(1.96 e-2) \quad(5.49 e-3)$ 


\section{Consequences of DBA-Case 3 with Non-Latching Blast Valves}

The blast from 55 \# HE was not sufficient to cause the GG collapse, or damage to the ventilation system of the assembly cell. Without venting through roof lift or gravel like in Cases $1 \& 2$, the pressure in the assembly cell remained high for an extended time, and the valve did not reopen until about $1430 \mathrm{sec}$ after the blast.

\subsection{Intrafacility Pu Transport}

The behavior of suspended Pu in the staging area (Figure 3) was similar to that with the latching valve until the reopening of the nor-latching valve at 1430 $\mathrm{sec}$. The reopened valve provided the only large flow path for this case, and a significant amount of $\mathrm{Pu}$ passed through the valve. Suspended $\mathrm{Pu}$ in the source location -the round room- was quickly depleted (Figure 14).

The build-up of suspended Pu in the corridor, decon room and radiography is shown in Figures $15 \& 16$. The Pu build-up in these buildings continued over a more extended time than in Cases $1 \& 2$, resulting in much higher concentration of respirable $\mathrm{Pu}$ in these locations. Figures $15 \& 16$ show that the build-up in the upstream corridor ceased after about $0.5 \mathrm{hr}$, while it continued in other locations for hours. After the valve reopened, $\mathrm{Pu}$ concentration in these DAF locations decreased to below that of the latching valve case.

\subsection{The Source Term}

Table 12 lists the unfiltered and filtered total release to the environment, with latching and non-latching valves. These source terms are also compared in Figure 17. Because the opened valve was the only large flow area, with no other significant competing leak paths, a large amount of Pu passed through the valve when it reopened at $1430 \mathrm{sec}$. The total unfiltered Pu release for the ron-latching case was $550.4 \mathrm{gm}$ compared to $8.2 \mathrm{gm}$ for the latching case. Out of the total unfiltered release of $550.4 \mathrm{gm} \mathrm{Pu}, 544 \mathrm{gm}$ passed through the reopened valve. All release paths for this case were equipped with HEPA filters, and assuming filter integrity, the total filtered source term was $0.55 \mathrm{gm}$ for the non-latching case, compared to $0.0082 \mathrm{gm}$ for the latching case.

\subsection{Occupational Consequences to DAF Personnel}

Because of the late valve reopening, the occupational doses received by DAF personnel within the first 20 minutes were not different from those with latching valves. These doses were calculated in Reference 2 . 


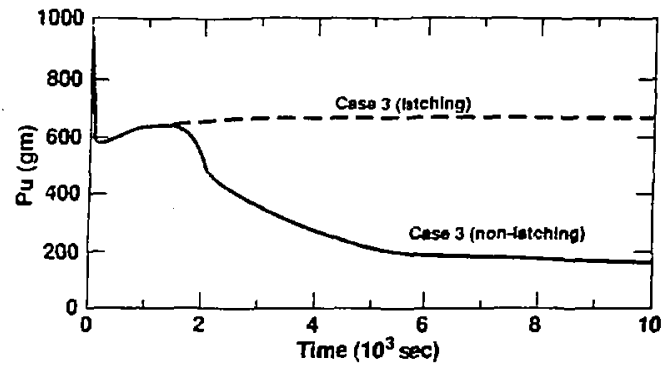

Figure 14. Comparison of total Pu in respirable slza range, in the gravel gertie tor Case 3, with latching and non-latching valve.

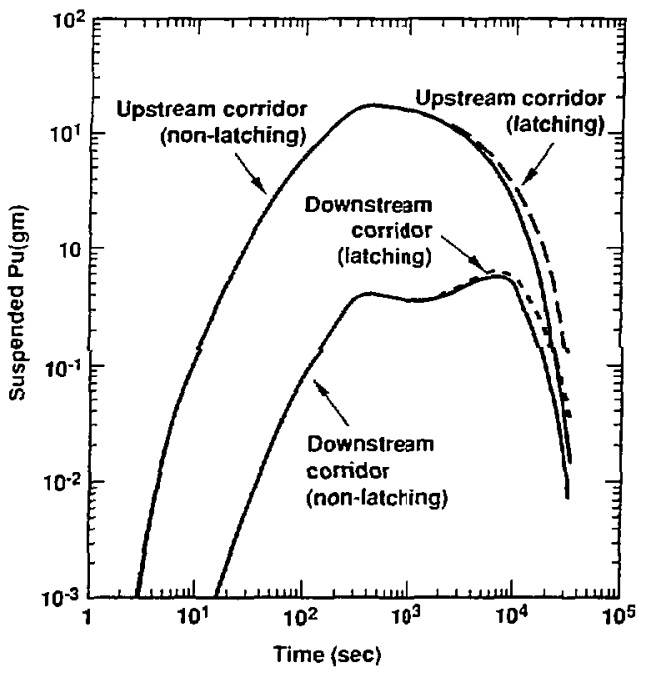

Figure 15. Suspended Pu in corridor: Comparison of behavior with latching and non-latching valve.

Case 3: $55 \mathrm{HHe}, 5 \mathrm{~kg} \mathrm{Pu}$ 


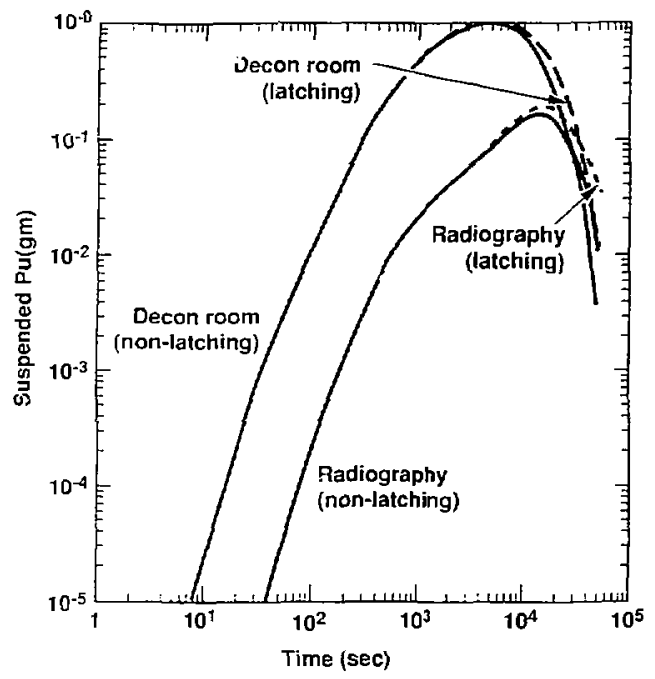

Figure 16. Suspended $\mathrm{Pu}$ in Decon roor and radiography building: Comparison of hehavior with latching and non-latching valve. Case 3: 55\# $5 \mathrm{~kg} \mathrm{Pu}$ 


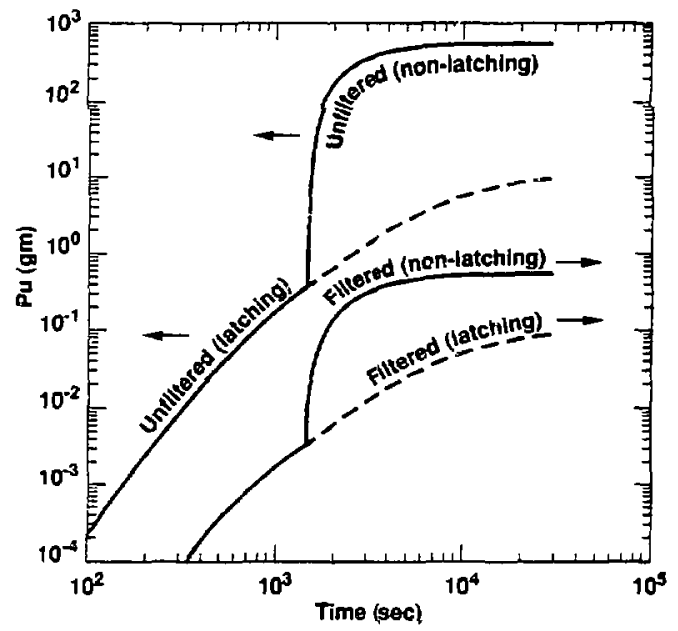

Figure 17. Pu released to environment (filtered and untiltered): Comparison of behavior with latching and non-latching valke. Case 3: 55HHE, $5 \mathrm{~kg} \mathrm{Py}$ 
Table 12

Source Term from DAF Design-Basis-Accident - Case 3(55\#HE, $5 \mathrm{~kg} \mathrm{Pu}$ ) (Cumulative release to environment)

\begin{tabular}{|c|c|c|c|c|}
\hline \multirow[t]{2}{*}{ Time(sec) } & \multicolumn{2}{|c|}{ Unfiltered Release(kg Pu) } & \multicolumn{2}{|c|}{ Filtered Release(kg Pu) } \\
\hline & latching & non-latching & latching & non-latching \\
\hline 1 & $4.938 \mathrm{e}-17$ & $4.938 e-17$ & $4.938 \sim-20$ & $4.938 e-20$ \\
\hline 2 & $1.640 \mathrm{e}-15$ & & $1.640=18$ & \\
\hline 3 & $2.161 \mathrm{e}-14$ & $2.161 \mathrm{e}-14$ & $2.161 \mathrm{e}-17$ & $2.161 \mathrm{e}-17$ \\
\hline 5 & $4.901 \mathrm{e}^{-13}$ & & $4.901 €-16$ & \\
\hline 10 & $1.508 e^{-11}$ & $1.508 \mathrm{e}-11$ & $1.508 e^{-14}$ & $1.5 C 3 \mathrm{e}-14$ \\
\hline 20 & $5.314 \mathrm{e}-10$ & & $5.314 e^{-13}$ & \\
\hline 40 & $7.936 \mathrm{e}-9$ & $7.936 e-9$ & $7.936 e-12$ & $7.936 \mathrm{e}-12$ \\
\hline 80 & $1.124 \mathrm{e}-7$ & & $1.124 \mathrm{e}-10$ & \\
\hline 110 & $3.500 e-7$ & $3.500 \mathrm{e}-7$ & $3.500 \mathrm{e}-10$ & $3.500 \mathrm{e}-10$ \\
\hline 240 & $4.560 e^{2}-6$ & & $4.560 \mathrm{e}-9$ & \\
\hline 440 & $2.648 e-5$ & $2.648 e-5$ & $2.648 \mathrm{e}-8$ & $2.648 e-8$ \\
\hline 890 & $1.385 e-4$ & & $1.385 e-7$ & \\
\hline 1240 & $2.710 e^{-4}$ & $2.710 e^{-4}$ & $2.710 \mathrm{e}-7$ & $2.710 e^{-7}$ \\
\hline 1430 & $3.556 e-4$ & $3556 e-4$ & $3.556 e-7$ & $3.556 \mathrm{e}-7$ \\
\hline 1432 & & $7.433 e-4$ & & $7.433 e^{-7}$ \\
\hline 1640 & $4.573 \mathrm{e}-4$ & & $4.573 \mathrm{e}-7$ & \\
\hline 1832 & & 0.1074 & & $1.074 e-4$ \\
\hline 2000 & $6.478 e-4$ & 0.1452 & $6.478 e-7$ & $1.45 \div 2-4$ \\
\hline 5000 & $2.497 e-3$ & 0.4478 & $2.497 e-6$ & $4.478 e-4$ \\
\hline 10000 & $5.027 e-3$ & 0.5179 & $5.027 e-6$ & $5.179 e-4$ \\
\hline 20000 & $7.436 \mathrm{e}-3$ & 0.5408 & $7.436 c-6$ & $5.408 e-4$ \\
\hline 30000 & $8.178 \mathrm{e}-3$ & 0.5504 & $3.17 \delta e-6$ & $5.504 e-4$ \\
\hline
\end{tabular}




\section{Comparison of Source Terms}

Following an accident involving $\mathrm{HE}$ and $\mathrm{Pu}$ in the assembly cell, there are several possible leak paths for Pu release to the environment: GG lifting, gravelfilled opening between the GG and staging area, reopened non-latching blast valve, and other ventilation exhaust ducts. It is informative to compare the components of the source term, that is, the total amount of $\mathrm{Pu}$ flowing through each leak path. We distinguish the "unfiltered source term" from the "filtered source term." The unfiltered source term is the amount of Pu entering a release path without any filtering. Conversely, the filtered source term is the release with all filtering methods (HEPA and gravel) operating at their expected efficiency. As a summary for the source term results, Tables $13 \& 14$ compare the unfiltered and filtered components of Pu release to the environment, with latching and non-latching blast valves. The total unfiltered and filtered release to the environment is compared in Table 15.

Table 13

Comparison of unfiltered source term components ( $\mathrm{gm} \mathrm{Pu}$ ) for the three DBAs, with latching $(\mathrm{L})$ and non-latching $(\mathrm{NL})$ valves

\begin{tabular}{llllllllll}
\hline DBA & \multicolumn{2}{c}{ Roof lift } & \multicolumn{2}{c}{ Gravel } & \multicolumn{2}{c}{ Valve } & \multicolumn{2}{c}{ Other } \\
& $\mathrm{L}$ & $\mathrm{NL}$ & $\mathrm{L}$ & $\mathrm{NL}$ & $\mathrm{L}$ & $\mathrm{NL}$ & $\mathrm{L}$ & $\mathrm{NL}$ \\
\hline Case 1 & 12.8 & 12.8 & 1788.4 & 1075.0 & 0.0 & 735.2 & 0.08 & 0.033 \\
Case 2 & 0.785 & 0.785 & 827.4 & 509.8 & 0.0 & 328.0 & $5.6 \mathrm{e}-3$ & $3.1 \mathrm{e}-3$ \\
Case 3 & 0.0 & 0.0 & 0.0 & 0.0 & 0.0 & 543.8 & 8.20 & 6.57 \\
\hline
\end{tabular}

Table 14

Comparison of filtered source term components (gm Pu) for the three DBAs, with Jatching $(L)$ and non-latching (NL) valves

\begin{tabular}{lccccccccc}
\hline DBA & \multicolumn{2}{c}{ Roof lift } & \multicolumn{2}{c}{ Gravel } & \multicolumn{2}{c}{ Valve } & \multicolumn{2}{c}{ Other } \\
& $\mathrm{L}$ & $\mathrm{NL}$ & $\mathrm{L}$ & $\mathrm{NL}$ & $\mathrm{L}$ & $\mathrm{NL}$ & $\mathrm{L}$ & $\mathrm{NL}$ \\
\hline Case 1 & 0.093 & 0.093 & 13.04 & 7.84 & 0.0 & 0.735 & $8.0 \mathrm{e}-5$ & $3.3 \mathrm{e}-5$ \\
Case 2 & $5.7 \mathrm{e}-3$ & $5.7 \mathrm{e}-3$ & 6.032 & 3.72 & 0.0 & 0.328 & $5.6 \mathrm{e}-6$ & $3.1 \mathrm{e}-6$ \\
Case 3 & 0.0 & 0.0 & 0.0 & 0.0 & 0.0 & 0.544 & $8.2 \mathrm{e}-3$ & $6.6 \mathrm{e}-3$ \\
\hline
\end{tabular}


The valve design had no effect on the release from GG lift, most of which took place prior to valve reopening. In Cases $1 \& 2$, there was less Pu flowing through the gravel when the valves were non-latching, because part of the $\mathrm{Pu}$ that would have flowed through gravel now passed through the reopened valve. We note that there was more Pu flowing through the reopened valve in Case 3 than in Case 2, although Case 2 involved a larger initial Pu mass; this was because for Case 3 , the opened valve was the only large venting area for $\mathrm{Pu}$ release. We also note that the release through the exhaust duct along the corridor was only a small component of the total release. For Case 3 , this component was more significant than for other cases, because there was a larger build-up of $\mathrm{Pu}$ in the corridor and in buildings along it.

Table 15

Comparison of total urfiltered and filtered source term ( $\mathrm{gm} \mathrm{Pu}$ ) for the three DBA5, with latching (L) and non-latching (NTL) valves

\begin{tabular}{ccccc}
\hline DBA & \multicolumn{2}{c}{ Total unfiltered } & \multicolumn{2}{c}{ Total filtered } \\
& $\mathrm{L}$ & $\mathrm{NL}$ & $\mathrm{L}$ & $\mathrm{NL}$ \\
\hline Case 1 & 1801.2 & 1823.0 & 13.13 & 8.69 \\
Case 2 & 828.2 & 838.6 & 6.04 & 4.05 \\
Case 3 & 8.18 & 550.4 & $8.18 \mathrm{e}-3$ & 0.550 \\
\hline
\end{tabular}

For Cases $1 \& 2$, the totai unfiltered release with non-latching valves was larger than with latching valves, bui not appreciably, due to the compensation effect between an increased flow area and a decrease in pressure differential as discussed in 4.2. For Case 3 , the opened valve was the only large venting area, causing a much larger release than that with latching valves.

Although the unfiltered release was larger with non-latching valves than with latching valves for all three cases, the filtered release was less with nonlatching valves for Cases $] \& 2$. This was because part of the Pu that would have flowed through gravel in these cases now passed through the opened valve duct equipped with high efficiency HEPA filters, which were assumed to function throughout the accident. For Case 3 however, the opened valve was the only large venting area (no flow through gravel), and both unfiliered and filtered releases with non-latching valves were much larger than those with latching ones. 


\section{References}

1. DOE 5480.23, Nuclear Safety Analysis Reports, Effective date: $4 / 30 / 92$

2. Dong H. Nguyen and Donald G. Rose, Containment Analysis of Design-Basis Accidents Involving High Explosives and Plutonium in the Assembly Cell of the Device Assembly Facility UCRL-LR-108991, Lawrence Livermore National Laboratory, April 1992

3. Letter dated May 5, 1993, John M. MCGrail, DOE/NV to James R. Page, LLNL 